\title{
ANALISIS DETERMINAN EFEKTIVITAS AUDITOR INTERNAL PADA INSPEKTORAT PROVINSI DAERAH ISTIMEWA YOGYAKARTA
}

\author{
Dea Nurfika Sari \\ Haryanto
}

Departemen Akuntansi Fakultas Ekonomika dan Bisnis Universitas Diponegoro

\begin{abstract}
The aims of this study is to examine factors that affect (determinants) internal audit effectiveness in the public sector, Inspectorate office at Province Special Region of Yogyakarta. This study is a replication of the research that has been done by Alzeban and Gwilliam in Saudi Arabia. There are 4 (four) independent variables that affect internal audit effectiveness as dependent variable. There are competence of internal auditor, the relationship between internal and external auditor, auditee support to internal audit activity, and independence of internal auditor. The population in this research is 51 internal auditor working in Inspectorate office at Province Special Region of Yogyakarta. This study uses primary data in the form of questionnaire. All of questionnaire can be processed. The datawere collected were processed using PLS analysis with SmartPLS 3 program. Statistical tests showed that three of four independent variables, there are the competence of the internal auditor, the auditee support and the independence of the internal auditor affect the effectiveness of the internal audit. while relationship between the internal auditor with the external auditor does not affect the internal audit effectiveness Keywords: Internal auditor effectiveness, competence of internal auditor, relationship between internal and external auditor, auditee support to internal audit activity, independence of internal auditor.
\end{abstract}

\section{PENDAHULUAN}

Audit merupakan kegiatan yang dilakukan dalam bentuk pemeriksaan pengujian suatu pernyataan guna memberikan suatu pendapat. Audit terdiri dari audit internal dan eksternal. Audit internal dilakukan oleh pihak yang disebut auditor internal. Pada mulanya, auditor internal dalam suatu lembaga memiliki fungsi sebagai watchdog yang terbatas pada pengendalian internal serta kepatuhan keuangan. Namun seiring perkembangan zaman, fungsi audit internal semakin tumbuh secara signifikan sebagai badan yang memberikan jasa konsultasi serta katalis dalam fungsi manajemen risiko suatu lembaga.

Audit internal merupakan audit yang dilakukan oleh unit pemeriksa yang merupakan bagian dari organisasi yang diawasi. Dalam Standar Audit Internal 
Pemerintah Indonesia telah disebutkan, fungsi audit internal sektor publik di Indonesia dilaksanakan oleh Aparat Pengawasan Internal Pemerintah (APIP), termasuk diantaranya inspektorat. Inspektorat merupakan instansi sektor publik yang secara umum bertugas untuk mengawasi pemerintah dalam pelaksanaan program kerja, anggaran dan sistem pemerintahan. Dengan diberlakukannya sistem pemerintahan daerah untuk membuat laporan keuangan yang menjamin desentralisasi, maka semakin besar tuntutan masyarakat akan transparansi dan akuntabilitas. Jika transparansi dan akuntabilitas terjamin, maka sistem pemerintahan akan semakin efektif. Efektivitas berkaitan dengan pencapaian tujuan (Mardiasmo, 2009). Efektivitas berarti menyediakan jasa-jasa yang benar sehingga memungkinkan pihak yang berwenang untuk mengimplementasikan kebijakan dan tujuannya. Pencapaian tujuan oleh sebuah organisasi menandakan bahwa organisasi tersebut telah berjalan secara efektif.

Efektivitas dalam tata kelola perusahaan sektor publik tercermin dari tercapainya tujuan pemerintah yang berkaitan dengan pengelolaan sumber daya sosial dan ekonomi untuk kepentingan pembangunan masyarakat.
Menurut UNDP, karakteristik good governance ditandai dengan adanya partisipasi, kerangka hukum yang adil, transparansi, sikap cepat tanggap dalam melayani stakeholder, sikap berorientasi pada kepentingan masyarakat, sikap adil, efisiensi dan efektivitas, akuntabilitas serta memiliki visi kedepan (Mardiasmo, 2009). Selain itu efektivitas dalam tata kelola perusahaan sektor publik juga tercermin dari aktivitas audit internal yang mendukung.Efektivitas dalam sektor publik juga dapat diukur dari sejauh mana auditor internal memiliki kompetensi yang memadai, jumlah sumber daya yang cukup, hubungan dengan auditor eksternal yang baik, adanya dukungan dari auditee serta independensi dari auditor itu sendiri. Tujuan dari penelitian ini adalah untuk menganalisis faktor-faktor yang mempengaruhi efektivitas auditor internal. Faktor-faktor tersebut diantaranya ialah kompetensi, hubungan antara auditor internal dengan eksternal, dukungan dari auditee serta independensi auditor. Dalam hal menguji efektivitas auditor internal, peneliti sebelumnya hanya meneliti dukungan auditee (Mihret dan Yismaw, 2007), dukungan manajemen dan independensi auditor (Cohen dan Sayag, 2009). Serta hubungan antara auditor internal dan 
eksternal (Alzeban dan Gwilliam, 2014).

Dari penelitian ini, faktor independensi auditor tidak memberikan dampak terhadap efektivitas auditor internal (Cohen dan Sayag, 2009).

\section{KERANGKA}

PEMIKIRAN

\section{TEORITIS DAN PERUMUSAN}

\section{HIPOTESIS}

Penelitian mengenai efektivitas auditor internal didasarkan pada teori keagenan yang dikemukakan oleh Jensen dan Meckling (1976). Teori keagenan merupakan teori yang menjelaskan mengenai perilaku agen, dimana adanya perbedaan kepentingan antara agen dan prinsipal yang menyebabkan asimetri informasi. Agen sebagai seorang pengendali perusahaan memiliki seluruh informasi dalam perusahaan. Hal ini tentu berbeda dengan prinsipal, yang mana sebagai pemilik prinsipal jarang berada di perusahaannya, sehingga aksesnya untuk memperoleh informasi sangat minim. Hal ini akan memicu agen untuk melakukan disfunctional behaviour, yaitu tindakan agen yang memanfaatkan aset perusahaan untuk kepentingan pribadinya. Di dalam penelitian ini terjadi hubungan agensi antara auditor internal pemerintah, yaitu Inspektorat Provinsi Daerah Istimewa Yogyakarta dengan
Pemerintah Provinsi Daerah Istimewa Yogyakarta. Pemerintah Provinsi Daerah Istimewa Yogyakarta bertindak sebagai prinsipal sebagai pihak yang memberi wewenang kepada agen. Sedangkan, Inspektorat Provinsi Daerah Istimewa Yogyakarta bertindak sebagai agen yang diberikan wewenang untuk memberikan jasa audit bagi Pemerintah Provinsi Daerah Istimewa Yogyakarta.

Penelitian mengenai efektivitas auditor internal juga berdasarkan teori kontingensi yang dikemukakan oleh Daft (2009). Kontingensi artinya sesuatu yang bergantung kepada sesuatu yang lain, dan untuk organisasi agar menjadi lebih efektif, harus ada "goodness of fit" diantara struktur dan kondisi lingkungan eksternal. teori kontingensi mampu membantu peneliti dalam menjelaskan suatu fenomena. Teori ini juga mampu menjelaskan hubungan antara 2 variabel atau lebih (Badara dan Saidin, 2014). Efektivitas auditor internal tidak dapat tercapai tanpa faktor-faktor yang mendukungnya. Dalam penelitian ini auditor internal bergantung pada variabel penghubung dari dalam yaitu kompetensi auditor dan independensi auditor, serta variabel penghubung dari luar yaitu hubungan antara auditor internal dan auditor eksternal serta dukungan auditee. 
Hubungan antara efektivitas auditor internal dengan kompetensi, hubungannya dengan auditor eksternal, dukungan auditee serta independensi auditor berdasarkan pemikiran bahwa semakin baik kompetensi yang dimiliki oleh seorang auditor, semakin intens hubungan antara auditor internal dan auditor eksternal, semakin besar dukungan auditee dan semakin independen auditor dalam melaksanakan tugasnya akan mempengaruhi tingkat efektivitas pada auditor internal.

Penelitian ini didasarkan pada sejumlah studi internasional sebelumnya yang menyelidiki dan mengevaluasi aspek kinerja audit internal dan efektivitas. Melalui penelitian di Italia, Arena dan Azzone (2009) menemukan bahwa karakteristik tim audit internal, proses audit dan kegiatan, dan link organisasi mempengaruhi efektivitas auditor internal. Menggunakan wawancara campuran dan metodologi angket di Ethiopia, Mihret dan Yismaw (2007) mengidentifikasi karakteristik organisasi yang meningkatkan atau menurunkan efektivitas auditor internal. Mereka menemukan bahwa kualitas audit internal sangat mempengaruhi efektivitas auditor internal. Namun, pengaturan dan auditee organisasi atribut yang pengaruh jauh lebih lemah. Selain itu, penelitian yang ada telah menggunakan berbagai ukuran efektivitas auditor internal, seperti pelaksanaan rekomendasi audit internal atau telah sesuai standar internasional. Penelitian ini menggunakan beberapa langkah dari efektivitas auditor internal, termasuk kemampuan dirasakan departemen untuk merencanakan, untuk meningkatkan produktivitas organisasi, untuk menilai konsistensi hasil dengan tujuan dan sasaran yang ditetapkan, untuk melaksanakan rekomendasi audit internal, untuk mengevaluasi dan meningkatkan manajemen risiko, untuk mengevaluasi internal yang sistem kontrol, dan memberikan rekomendasi untuk perbaikan. Selanjutnya, penelitian ini mencoba untuk menjelaskan persepsi pemangku kepentingan dari efektivitas auditor internal menggunakan ukuran kompetensi auditor, ukuran departemen audit internal, hubungan antara auditor internal dan eksternal, independensi audit internal, dan tingkat dukungan manajemen untuk fungsi audit internal. Untuk mempermudah pemahaman atas penelitian ini yang digambarkan kerangka pemikiran sebagai berikut: 


\section{Gambar 1}

\section{Kerangka Pemikiran Teoritis}

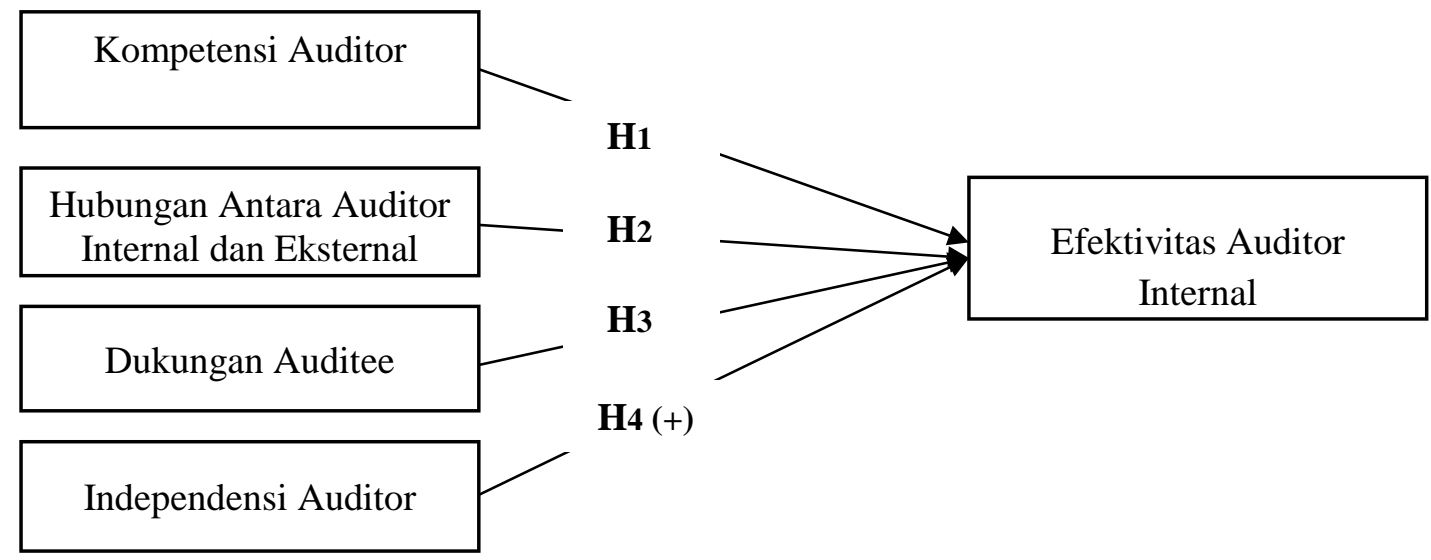

Gambar di atas menggambarkan hubungan antar variabel-variabel dalam penelitian yang dilakukan. Variabel independen dalam hipotesis 1 adalah kompetensi auditor internal yang mengarah pada variabel efektivitas auditor internal sebagai variabel dependen. Dalam hipotesis 2, hipotesis 3, dan hipotesis 4 variabel independennya adalah hubungan auditor internal dan eksternal, dukungan auditee serta independensi auditor sebagai variabel dependen. Garis lurus pada gambar memiliki arti bahwa adanya pengaruh antara variabel independen dengan dependen yang membentuk hipotesis dalam penelitian ini.

\section{Pengaruh Kompetensi Auditor}

Internal Terhadap Efektivitas Auditor

\section{Internal}

Kompetensi auditor adalah kemampuan yang dimiliki oleh seorang auditor dalam hal mengimplementasikan apa yang ia ketahui sebagai wujud pemahamannya terhadap proses audit. Kompetensi yang dimiliki auditor dapat diukur dengan tiga komponen yaitu tingkat pendidikan, lamanya seorang auditor bernaungan dengan dunia audit serta jumlah jam pelatihan tahunan yang telah dilalui auditor.

Seorang auditor diharapkan memiliki pendidikan tinggi. Semakin tinggi pendidikan yang dia tempuh akan 
semakin menunjukkan potensinya dalam melakukan pekerjaan profesional, salah satu jenisnya ialah pekerjaan audit. Seorang auditor yang berpendidikan tinggi akan cenderung dipandang telah memiliki banyak pengalaman dan lebih mudah untuk diberi kepercayaan.

Jumlah waktu lamanya seorang auditor bernaung di dunia audit juga menjadi salah satu komponen penentu kompetensi auditor tersebut. Seorang auditor yang sudah berpengalaman lebih dari 10 tahun tentunya akan lebih dianggap berkompeten dibandingkan dengan seorang junior auditor yang baru berpengalaman kurang dari 5 tahun. Hal tersebut dikarenakan untuk menjadi seorang auditor yang handal diperlukan ‘jam terbang' yang cukup memadai.

Selanjutnya, jumlah pelatihan audit yang telah diikuti juga menjadi salah satu komponen penentu kompetensi auditor. Pelatihan audit merupakan salah satu langkah untuk menambah kompetensi seorang auditor. Tidak dapat dipungkiri, dalam mengikuti suatu pelatihan akan selalu ada hal baru yang ditemukan serta dapat dipelajari. Oleh karena itu, semakin banyak pelatihan yang diikuti oleh seorang auditor, akan semakin menunjukkan kemampuannya di bidang tersebut.
Untuk melaksanakan audit di sektor pemerintahan, auditor tidak hanya membutuhkan keahlian dan pengalaman, melainkan harus memahami seluruh aspek yang berkaitan dengan pemerintahan, seperti struktur organisasi, fungsi program, dan kegiatan pemerintah sehingga akan lebih memudahkan auditor tersebut melaksakan pekerjaannya sebagai auditor internal pemerintah dengan menggunakan standar akuntansi dan auditing yang ditetapkan sebagai pedomannya (Efendy, 2010).

Beberapa penelitian sebelumnya fokus terhadap kebutuhan individu dalam memenuhi kualifikasi sesuai untuk mencapai tingkat efektivitas auditor internal yang lebih tinggi. Menurut Mihret \& Yismaw (2009), staf audit internal yang memiliki kualifikasi pendidikan yang kurang serta pelatihan yang minim sangat dimungkinkan untuk memperbaiki keterampilan mereka. Sedangkan menurut Alzeban dan Gwilliam (2014) minimnya kualifikasi staf menjadi salah satu faktor yang membatasi fngsi audit internal.

Berdasarkan uraian di atas, hipotesis yang dapat dirumuskan adalah:

\section{H1. Kompetensi auditor internal berpengaruh positif terhadap efektivitas auditor internal.}


Pengaruh Hubungan Antara Auditor

Internal Dan Auditor Eksternal

Terhadap Efektivitas Auditor Internal

Dalam menjalankan tugasnya,

audit internal perlu melakukan koordinasi dengan auditor eksternal. Koordinasi yang dilakukan dapat berupa pertukaran informasi, opini, perencanaan audit bersama maupun laporan audit dalam rangka mewujudkan hasil audit yang berkualitas serta menghindari duplikasi kerja diantara mereka sehingga akan lebih efisien.

Studi akademis sebelumnya menunjukkan bahwa kerjasama yang tepat antara auditor internal dan eksternal akan meningkatkan ekonomi, efisiensi, serta efektivitas audit dan membantu manajemen memberikan pelayanan publik yang berkualitas tinggi. Menurut Al-Garni dan Almohaimeed (dalam Alzeban dan Sawan, 2013), kurangnya kerjasama antara Inspektorat, yang mana merupakan organisasi yang melakukan audit di sektor pemerintahan, serta organisasi yang diaudit dipengaruhi oleh efektivitas auditor eksternal.

Berdasarkan uraian di atas, hipotesis yang dapat dirumuskan adalah:

H2. Hubungan antara auditor internal dengan auditor eksternal berpengaruh positif terhadap efektivitas auditor internal.

\section{Pengaruh Dukungan Auditee}

Terhadap Efektivitas Auditor Internal

Audit internal akan menghasilkan tata kelola pemerintahan yang baik, yang mana sebagian bergantung pada profesionalisme manajemen sebagai auditee untuk memastikan fungsi audit internal yang ketat. Dukungan auditee terhadap kegiatan audit internal diwujudkan dengan memberikan kebebasan terhadap auditor internal untuk memperoleh sumber yang mencukupi dalam rangka melaksanakan tugas dan tanggung jawab mereka. SPPIA menyoroti pentingnya hubungan antara audit internal dan manajemen perusahaan sebagai auditee. Manajemen, dalam kasus ini konteksnya ialah pegawai pemerintah, harus terlibat dalam rencana audit internal. Salah satu bentuk keterlibatannya ialah dengan menanggapi serta mempertimbangkan input dari auditor internal tersebut. Dengan adanya tanggapan tersebut, auditor internal akan terdorong untuk dapat melakukan pekerjaannya dengan baik. Pemberian informasi yang jelas dan sesuai fakta dari pegawai pemerintahan juga akan 
mempermudah pekerjaan auditor dalam menyelesaikan pekerjaannya.

Pegawai pemerintahan perlu menyadari pentingnya proses audit internal dalam mewujudkan kredibilitas istansi mereka. Apabila kesadaran tersebut sudah dimiliki, maka mereka tidak perlu merasa khawatir dengan adanya pelaksnaan audit internal. Mereka justru akan memberikan respon positif sehingga meningkatkan efektivitas pelakanaan audit internal.

Beberapa studi sebelumnya menyatakan bahwa dukungan auditee adalah salah satu faktor penentu utama dalam keberhasilan fungsi audit internal. Dengan dukungan auditee rekomendasi audit internal akan lebih mungkin untuk dilaksanakan dan audit internal akan memperoleh sumber daya yang baik dalam segi staff maupun anggatan untuk pelaksanaan audit internal tersebut. Audit internal membutuhkan penerimaan dan apresiasi klien atas kontribusi yang diberikan bagi organisasi sebagai hasil dari pekerjaannya.

Berdasarkan uraian di atas, hipotesis yang dapat dirumuskan adalah:

H3. Dukungan auditee berpengaruh positif terhadap efektivitas auditor internal.

\section{Pengaruh Independensi Auditor} Terhadap Efektivitas Auditor Internal Independensi auditor telah lama dipandang sebagai pendorong utama peran auditor. Meski terdapat penekanan secara historis terhadap independensi auditor eksternal, badan profesional serta para penyusun standar telah menempatkan peningkatan bobot terhadap kebutuhan akan indepedensi serta objektivitas disamping fakta bahwa auditor internal biasanya merupakan karyawan dari instansi yang bersangkutan. Independensi dan objektivitas yang tepat diperoleh dengan melakukan tanggung jawabnya bebas dari campur tangan, menghindari konflik kepentingan, memiliki kontak langsung dengan dewan dan manajemen senior, memiliki akses tak terbatas terhadap catatan, karyawan serta departemen, memiliki sistem pengangkatan dan pemberhentian kepala audit internal yang tidak berada di bawah kontrol langsung dari manajemen eksekutif, serta tidak melakukan pekerjaan non-audit.

$$
\text { Penelitian sebelumnya }
$$

menunjukkan bahwa kurangnya independensi merupakan suatu penghalang bagi kinerja audit internal di sejumlah negara. Auditor internal harus melaporkan ke tingkat tertinggi dalam 
organisasi untuk memastikan bahwa tindakan korektif yang diambil ialah untuk mengimplementasikan rekomendasi dari auditor internal tersebut.

Berdasarkan uraian di atas, hipotesis yang dapat dirumuskan adalah :

H4. Independensi auditor internal berpengaruh positif terhadap efektivitas auditor internal.

\section{METODE PENELITIAN}

Variabel Penelitian

Variabel Dependen

Variabel dependen merupakan variabel terikat yang akan dipengaruhi oleh variabel bebas. Dalam penelitian ini yang menjadi variabel dependennya adalah Efektivitas auditor internal. Variabel ini diukur dengan indikator kemampuan dalam merencanakan, peningkatan produktivitas organisasi, penilaian konsistensi hasil dengan tujuan, pelaksanaan rekomendasi audit, evaluasi dan peningkatan manajemen risiko, evaluasi sistem pengendalian internal serta rekomendasi dalam rangka perbaikan.

\section{Variabel Independen}

Variabel independen adalah variabel bebas yang akan mempengaruhi variabel terikat. Dalam penelitian ini terdapat empat variabel independen, yaitu kompetensi auditor internal, hubungan antara auditor interrnal dan auditor eksternal, dukungan auditee terhadap kegiatan audit internal serta independensi auditor internal.

\section{Kompetensi Auditor}

Kompetensi adalah elemen kunci dalam kegiatan audit internal yang efektif (IIA, 2006). Selain itu, kompetensi telah diidentifikasi sebagai indikator ketergantungan pada pekerjaan audit internal oleh audit eksternal (Al-Twaijry et al., 2004). Oleh karena itu, kualifikasi yang cukup harus dimiliki oleh auditor dalam melaksanakan tugas serta kewajibannya.

Sukriah dkk. (2009) dalam penelitiannya mengukur kompetensi auditor berdasarkan lamanya bekerja sebagai auditor serta nanyaknya tugas pemeriksaan yang telah dilakukan.

Kemudian, Stephen Robbin (2007) mengukur kompetensi dalam 2 indikator yaitu kemampuan fisik dan kemampuan intelektual. Kemampuan fisik dapat berupa kemampuan seorang auditor dalam melaksanakan pekerjaan audit, sedangkan kemampuan intelektual 
contohnya adalah pendidikan yang telah ditempuh oleh auditor.

Alzeban dan Gwilliam (2014) dalam penelitiannya telah menyebutkan 4 (empat)indikator kompetensi dalam mengukur efektivitas audit internal. Indikator-indikator tersebut adalah kualifikasi pendidikan, kualifikasi profesionalitas, pengalaman kerja di bidang audit internal serta pengembangan yang berkelanjutan (rata-rata jam pelatihan tahunan).

Penilaian ini menggunakan skala likert, yakni antara "sangat tidak setuju" hingga "sangat setuju".

\section{Hubungan Antara Auditor Internal dan Auditor Eksternal}

Koordinasi dan kerjasama antara auditor internal dan eksternal telah lama dilihat sebagai hal penting dan bermanfaat dalam rangka audit bagi pemangku kepentingan. Contoh koordinasi dan kerja sama tersebut meliputi perencanaan bersama dan pertukaran informasi, opini serta laporan untuk menfasilitasi audit berkualitas tinggi dalam mencegah duplikasi yang tidak perlu, semisal dua kali kerja. Hubungan baik antara auditor internal dan auditor eksternal sangat mempengaruhi keefektifan departemen audit internal. Pekerjaan audit akan lebih ringkas dan cepat terselesaikan dengan adanya akses dari auditor internal terhadap auditor eksternal, sehingga secara langsung menjadikannya lebih efektif.

SIAS (Statement of Internal Audit Standards) no.5 yang diterbitkan oleh IIA menjelaskan bahwa pekerjaan audit internal dan eksternal harus dikoordinasikan untuk memastikan cakupan audit yang memadai dalam meminimalkan duplikasi pekerjaan audit. Kemudian perlu dilakukan koordinasi antar keduanya dalam hal pertemuan secara berkala untuk membahas permasalahan perusahaan, pengaksesan program audit dan kertas kerja satu sama lain, pertukaran laporan audit serta pemahaman atas teknik, metode dan istilah audit.

Alzeban dan Gwilliam (2014) dalam penelitiannya telah menyebutkan 7 (tujuh) indikator hubungan auditor internal dan eksternal dalam mengukur efektivitas audit internal. Indikatorindikator tersebut adalah sikap terhadap auditor eksternal, koordinasi, termasuk membahas kepentingan bersama, pembahasan rencana audit, ketergantungan auditor eksternal terhadap pekerjaan auditor internal, 
frekuensi pertemuan antara auditor internal dan auditor eksternal, pertukaran kertas kerja laporan keuangan antara auditor internal dan eksternal serta promosi manajemen terkait hubungan antara keduanya

Penilaian ini menggunakan skala likert, yakni antara "sangat tidak setuju" hingga "sangat setuju".

\section{Dukungan Auditee}

Dukungan auditee terhadap pekerjaan audit internal mempengaruhi keefektifan audit internal. Wujud dari dukungan yang diberikan oleh auditee berupa kebebasan dalam mengakses segala kebutuhan auditor internal di dalam melaksanakan pekerjaannya. Dengan dukungan dari auditee, auditor internal dapat memperoleh sumber yang mencukupi untuk melaksanakan tugasnya.

Auditee sepenuhnya harus menyadari akan kepentingan pemeriksaan yang dilakukan seorang auditor internal di perusahaannya dalam tujuan pemberian solusi akan segala permasalahan yang ada. Sehingga auditee seharusnya tidak perlu khawatir akan segala hal yang akan terjadi karena semua tindakan yang dilakukan oleh auditor internal semata-mata demi memberikan dampak positif kepada perusahaannnya.

Badara dan Saidin (2014) menyebutkan bahwa setiap organisasi dalam prosesnya untuk mencapai tujuan dan penetapan sejauh mana keberhasilan dapat dicapai memerlukan dukungan dari auditee. Dukungan ini terdiri atas berbagai indikator diantaranya tersedianya waktu, biaya, dan sumber daya baik manusia maupun keuangan untuk mendukung kegiatan organisasi dalam usaha untuk mencapai tujuan organisasi.

Alzeban dan Gwilliam (2014) dalam penelitiannya telah menyebutkan 4 (empat) indikator dukungan auditee dalam mengukur efektivitas audit internal. Indikator-indikator tersebut adalah dukungan bagi auditor internal untuk melaksanakan tugas dan tanggungjawabnya, kesempatan yang diberikan kepada auditor internal untuk melaksanakan audit, pemberian informasi yang sesuai oleh klien terhadap auditor internal serta tingkat penerimaan klien terhadap rekomendasi hasil audit yang diberikan oleh auditor internal.

Penilaian ini menggunakan skala likert, yakni antara "sangat tidak setuju" hingga "sangat setuju". 


\section{Independensi Auditor}

Menurut Alzeban dan Gwilliam (2014), independensi auditor telah lama dipandang sebagai pendorong utama peran auditor. Hubungan antara auditor internal dengan auditor eksternal mencakup kooperasi dan koordinasi antara keduanya. Koordinasi antara aktivitas audit internal dengan audit eksternal perlu dilakukan. Sebab dengan itu, eksternal auditor memiliki kemungkinan untuk meningkatkan efisiensi dalam mengaudit laporan keuangan. Begitu juga dengan pihak audit internal. Dia merasa terjamin dalam mengaudit laporan keuangan ditambah informasi yang penting dalam penilaian kontrol risiko.

Auditor dituntut untuk memiliki objectivity, komunikasi yang efektif, keahlian, due professional care, pengembangan dan pelatihan yang dapat meningkatkan keefektifan audit internal (Khaled dan Endaya, 2013). Independensi adalah wujud dali keobjektifan yang diterapkan oleh auditor, khususnya auditor internal. Sebab, dalam kenyataannya seorang auditor internal berpotensi memiliki tingkat independensi yang lebih rendah dari auditor eksternal karena posisi dimana ia bekerja, yaitu dibawah naungan instansi dimana ia melakukan pekerjaan audit.

Arens dan Loebbecke (1997) mengkategorikan independensi ke dalam dua aspek yaitu independensi dalam kenyataan serta independensi dalam penampilan. Independensi dalam kenyataan adalah apabila auditor berhasil mempertahankan sikap yang tidak bias selama melakukan pekerjaannya, sedangkan independensi dalam penampilan adalah hasil persepsi pihak lain tergadao independensi auditor internal.

SEC (Securitas Exchange Committee) sebagai badan yang juga berkepentingan terhadap audior yang independen memberikan definisi lain berkaitan dengan independensi. SEC memberikan empat prinsip dalam menentukan auditor yangindependen. Prinsip-prinsip ini menyatakan bahwa independensi dapat terganggu apabila auditor : memiliki konflik kepentingan dengan klien, mengaudit pekerjaan mereka sendiri, berfungsi baik sebagai manajer ataupun pekerja dari kliennya, bertindak sebagai penasehat bagi kliennya (Ryan et al, 2001) dalam Meutia (2004).

Alzeban dan Gwilliam (2014) dalam penelitiannya telah menyebutkan 8 
(delapan) indikator independensi dalam mengukur efektivitas audit internal. Indikator-indikator tersebut adalah tingkat kemandirian, tingkat pelaporan, kontak langsung dengan dewan manajemen senior, konflik kepentingan, gangguan, akses tak terbatas ke semua departemen dan karyawan serta pengangkatan dan pemberhentian kepala audit internal.

Penilaian ini menggunakan skala likert, yakni antara "sangat tidak setuju" hingga "sangat setuju".

\section{Penentuan Sampel}

Dalam penelitian ini, populasi yang digunakan oleh peneliti ialah auditor internal yang bekerja di Inspektorat seluruh Indonesia. Sedangkan sampel yang digunakan ialah auditor internal yang bekerja di Inspektorat Provinsi Daerah Istimewa Yogyakarta yang berjumlah 51 responden.

\section{Metode Analisis}

Pengujian hipotesis dilakukan dengan analisis PLS (Partial Least
Square). Analisis dalam penelitian ini terdiri dari tiga tahap. Tahap yang pertama merupakan statitsik deskriptif analisis demografi responden. Tahap kedua ialah uji instrumen data yang terdiri dari uji convergent validity, discriminant validity, reliabilitas cronbach alpha dan composit reliability. Tahap ketiga ialah uji hipotesis inner model.

\section{Deskripsi Sampel Penelitian}

Sampel dalam penelitian ini adalah auditor internal pada Inspektorat Provinsi Daerah Istimewa Yogyakarta. Sampel yang digunakan dalam penelitian menggunakan metode area sampling. Jenis data yang digunakan dalam penelitian ini adalah data primer. Data primer merupakan sumber data penelitian yang diperoleh secara langsung dari sumber asli (Indriantoro dan Supomo, 2002). Data dalam penelitian ini diperoleh melalui kuesioner yang disebarkan ke responden penelitian, yaitu auditor internal Inspektorat Provinsi Daerah Istimewa Yogyakarta 


\section{Deskripsi Variabel}

\section{Tabel 1}

Karakteristik Responden

\begin{tabular}{|c|c|c|}
\hline Karakteristik Responden & Jumlah & Presentase \\
\hline \multicolumn{3}{|l|}{ Jenis Kelamin } \\
\hline Pria & 31 & 60,8 \\
\hline Wanita & 20 & 39,2 \\
\hline Total & 51 & 100,0 \\
\hline \multicolumn{3}{|l|}{ Jabatan } \\
\hline Kasubag Program dan Keuangan & 1 & 2,0 \\
\hline Auditor Madya & 9 & 17,6 \\
\hline Auditor Muda & 14 & 27,5 \\
\hline Auditor Pertama & 11 & 21,6 \\
\hline Auditor Penyelia & 5 & 9,8 \\
\hline P2UPD & 6 & 11,8 \\
\hline Magang Auditor & 5 & 9,8 \\
\hline Total & 51 & 100,0 \\
\hline \multicolumn{3}{|l|}{ Pendidikan Terakhir } \\
\hline Akuntansi & 21 & 41,2 \\
\hline Manajemen & 9 & 17,6 \\
\hline Administrasi Publik & 5 & 9,8 \\
\hline Hukum & 8 & 15,7 \\
\hline Teknik & 7 & 13,7 \\
\hline Kehutanan & 1 & 2,0 \\
\hline Total & 51 & 100,0 \\
\hline \multicolumn{3}{|c|}{ Pengalaman Kerja di Bidang Audit } \\
\hline$<1$ tahun & 2 & 3,9 \\
\hline $1-5$ tahun & 5 & 9,8 \\
\hline 5-10 tahun & 17 & 33,3 \\
\hline 10-15 tahun & 18 & 35,3 \\
\hline$>15$ tahun & 9 & 17,6 \\
\hline Total & 51 & 100,0 \\
\hline \multicolumn{3}{|c|}{ Pelatihan yang Diikuti dalam Satu Tahun } \\
\hline$<20$ jam & 11 & 21,6 \\
\hline $21-40$ jam & 14 & 27,5 \\
\hline $41-80$ jam & 15 & 29,4 \\
\hline $81-120$ jam & 5 & 9,8 \\
\hline$>120 \mathrm{jam}$ & 6 & 11,8 \\
\hline Total & 51 & 100,0 \\
\hline
\end{tabular}

Sumber : Data primer yang diolah tahun 2016 
Dari table 1 di atas, kita dapat menyimpulkan bahwa jumlah responden secara keseluruhan ialah berjumlah 51 orang, 31 orang atau sekitar 60,8\% berjenis kelamin pria, dan sisanya yaitu 20 orang atau sekitar 39,2\% merupakan responden berjenis kelamin wanita.

Dari 51 orang responden, 1 orang atau sekitar 2\% merupakan seorang auditor senior yang menjabat sebagai Kasubag Keuangan, 9 orang atau sekitar 17,6\% merupakan auditor madya, 14 orang atau sekitar $27,5 \%$ merupakan auditor muda, 11 orang atau sekitar 21,6\% merupakan auditor pertama, 5 orang atau sekitar 9,8\% merupakan auditor penyelia, 6 orang atau sekitar 11,8\% merupakan P2UPD serta 5 orang atau sekitar 9,8\% merupakan magang auditor.
Dilihat dari latar belakang pendidikannya, auditor yang berlatar belakang pendidikan jurusan Akuntansi sebanyak 21 orang atau sekitar 41,2\%, jurusan manajemen sebanyak 9 orang atau sekitar 17,6\%, jurusan administrasi publik 5 orang atau sekitar $9,8 \%$, jurusan hukum 8 orang atau sekitar $15,7 \%$, teknik sebanyak 7 orang atau sekitar 13,7\%, serta kehutanan 1 orang atau sekitar $2 \%$.

Berdasarkan jumlah jam pelatihan audit dalam setahun, auditor yang memiliki jam pelatihan kurang dari 20 jam sebanyak 11 orang atau sekitar 21,6\%, 21 hingga 40 jam sebanyak 14 orang atau sekitar 27,5\%, 41 hingga 80 jam sebanyak 15 orang atau sekitar 29,4\%, 81 hingga 120 jam sebanyak 5 orang atau sekitar 9,8\% serta lebih dari 120 jam sebanyak 6 orang atau sekitar $11,8 \%$.

Tabel 2

Statistik Deskriptif

\begin{tabular}{|c|c|c|c|c|c|}
\hline Variabel & N & Minimum & Maximum & Mean & Std. Deviation \\
\hline $\begin{array}{c}\text { Efektivitas Auditor } \\
\text { Internal }\end{array}$ & 51 & 38,00 & 51,00 & 44,4510 & 2,59472 \\
\hline Kompetensi Auditor & 51 & 4,00 & 15,00 & 9,7647 & 2,54235 \\
\hline $\begin{array}{c}\text { Hubungan Antara } \\
\text { Auditor Internal dan } \\
\text { Auditor Eksternal }\end{array}$ & 51 & 21,00 & 32,00 & 26,0980 & 2,80895 \\
\hline Dukungan Auditee & 51 & 18,00 & 25,00 & 20,3725 & 1,23225 \\
\hline Independensi Auditor & 51 & 24,00 & 35,00 & 27,3725 & 1,98958 \\
\hline
\end{tabular}

Sumber : Data primer yang diolah tahun 2016 
Berdasarkan tabel 2 pada uji statistik deskriptif total sampel yang digunakan dalam penelitian $(\mathrm{N})$ adalah 51 responden. Adapun kisaran nilai sesungguhnya yaitu 38 sampai dengan 51. Selain itu, nilai standar deviasi tingkat penerapan akuntansi akrual adalah sebesar 2,5972. Nilai rata-rata efektivitas auditor internal untuk jumlah seluruh item pertanyaan adalah 44,4510. Tingkat efektivitas auditor internal dalam penelitian ini adalah sebesar $87,15 \%$ yang berasal dari 44,4510 dibagi dengan total responden dikali $100 \%$. Berdasarkan keterangan tersebut, dapat dikatakan bahwa tingkat keefektifan auditor internal di Inspektorat Provinsi DIY sudah sangat baik.

Variabel kompetensi mempunyai kisaran aktual antara 4 sampai dengan 15 , dimana kisaran teoritisnya adalah 3 sampai dengan 15 dengan nilai rata-rata 9,7647 serta standar deviasi 2,54235. Hal ini menjelaskan bahwa kompetensi auditor internal dalam mewujudkan efektivitas auditor internal sudah cukup memadai.

Untuk variabel hubungan antara auditor internal dengan auditor eksternal memiliki kisaran aktual antara 21 sampai dengan 32 dimana kisaran teoritisnya antara 7 sampai dengan 35 dengan nilai rata-rata 26,0980 dan standar devisiasi sebesar 2,80895. Hal tersebut menunjukkan bahwa hubugan antara auditor internal dan eksternal dalam mewujudkan efektivitas auditor internal sudah cukup memadai.

Untuk variable dukungan auditee memiliki kisaran aktual antara 18 sampai dengan 25 dimana kisaran teoritisnya anatara 5 sampai dengan 25 dengan nilai rata-rata 20,3725 dan standar devisiasi sebesar 1,23225. Hal tersebut menunjukkan bahwa dukungan auditee dalam mewujudkan efektivitas auditor internal sudah cukup memadai.

Untuk variabel independensi auditor memiliki kisaran aktual antara 38 sampai dengan 51 dimana kisaran teoritisnya anatara 7 sampai dengan 35 dengan nilai rata-rata 27,3725 dan standar devisiasi sebesar 1,98958. Hal tersebut menunjukkan bahwa independensi auditor dalam mewujudkan efektivitas auditor internal sudah cukup memadai.

\section{Pembahasan Hasil Penelitian}

Data yang telah dirinci kemudian diolah dengan program SmartPLS 3, model dihasilkan dengan menggunakan PLS Algorithm dan Bootstrapping. Berikut adalah tampilan dari PLS Algorithm dan Bootstrapping : 
Gambar 2

Hasil Model Pengukuran

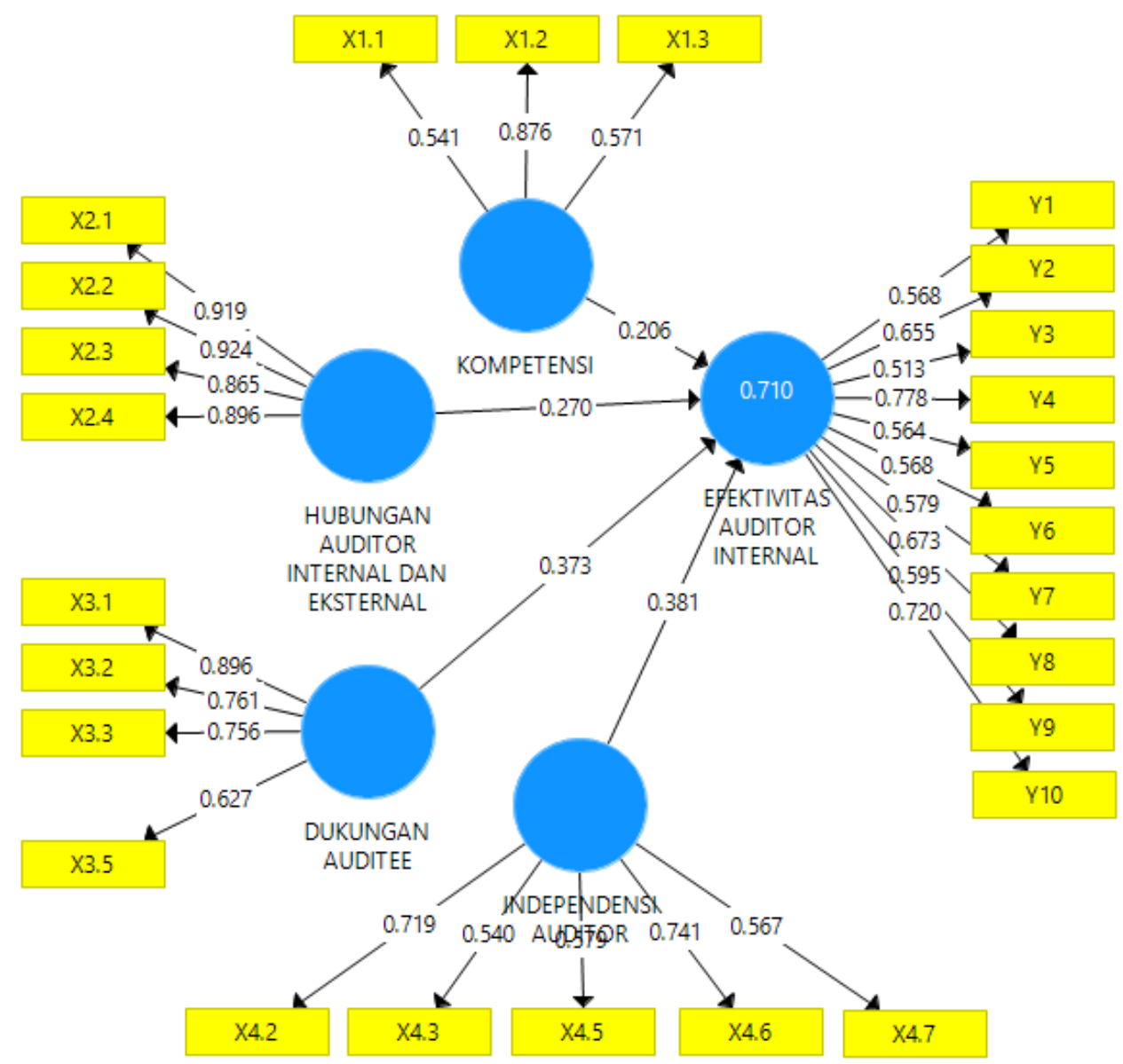

Sumber : Data primer yang diolah tahun 2017

Berdasarkan pada gambar 2 di atas dapat dijelaskan bahwa seluruh item pertanyaan yang menjadi indikator penelitian terbilang valid karena seluruhnya memiliki nilai diatas 0,5 .
Kemudian nilai 0,71 menandakan bahwa seluruh variabel independen mampu menjelaskan variabel dependen sebesar $71 \%$. 
Tabel 3

Hasil Pengujian Hipotesis

\begin{tabular}{|l|c|c|c|c|c|}
\hline & $\begin{array}{c}\text { Origina } \\
\boldsymbol{l} \\
\text { Sample } \\
(\boldsymbol{O})\end{array}$ & $\begin{array}{c}\text { Sample } \\
\text { Mean } \\
(\boldsymbol{M})\end{array}$ & $\begin{array}{c}\text { Standard } \\
\text { Deviation } \\
(\text { STDEV })\end{array}$ & $\begin{array}{c}\text { T Statistics } \\
(\mid \text { O/STDEV } \mid \\
)\end{array}$ & $\begin{array}{c}\boldsymbol{P} \\
\text { Values }\end{array}$ \\
\hline $\begin{array}{l}\text { KOMPETENSI -> EFEKTIVITAS } \\
\text { AUDITOR INTERNAL }\end{array}$ & 0,206 & 0,200 & 0,086 & 2,395 & 0,017 \\
\hline $\begin{array}{l}\text { HUBUNGAN AUDITOR INTERNAL } \\
\text { DAN EKSTERNAL -> EFEKTIVITAS } \\
\text { AUDITOR INTERNAL }\end{array}$ & 0,270 & 0,248 & 0,145 & 1,864 & 0,063 \\
\hline $\begin{array}{l}\text { DUKUNGAN AUDITEE -> } \\
\text { EFEKTIVITAS AUDITOR INTERNAL }\end{array}$ & 0,373 & 0,362 & 0,123 & 3,038 & 0,003 \\
\hline $\begin{array}{l}\text { INDEPENDENSI AUDITOR -> } \\
\text { EFEKTIVITAS AUDITOR INTERNAL }\end{array}$ & 0,381 & 0,408 & 0,136 & 2,807 & 0,005 \\
\hline
\end{tabular}

Sumber : data primer yang diolah tahun 2017

\section{Hipotesis 1}

Variabel kompetensi auditor secara signifikan berpengaruh positif terhadap efektivitas auditor Semakin tinggi kompetensi yang dimiliki seorang auditor, maka semakin efektif pula auditor tersebut dalam menjalankan tugasnya. Hasil ini ditandai dengan nilai T-statistik yang memiliki nilai >1,96 yaitu 2,395 dan $\mathrm{P}$-value $<0,05$ yaitu 0,017 .

\section{Hipotesis 2}

Variabel hubungan antara auditor internal dan eksternal tidak berpengaruh terhadap efektivitas auditor Hasil ini ditandai dengan nilai T-statistik yang memiliki nilai <1,96 yaitu 1,864 dan Pvalue $>0,05$ yaitu 0,063 .

\section{Hipotesis 3}

Variabel dukungan auditee secara signifikan berpengaruh positif terhadap efektivitas auditor Semakin tinggi dukungan yang diberikan oleh auditee, maka semakin efektif pula auditor tersebut dalam menjalankan tugasnya. Hasil ini ditandai dengan nilai T-statistik yang memiliki nilai >1,96 yaitu 3,038 dan P-value $<0,05$ yaitu 0,003.

\section{Hipotesis 4}

Variabel independensi auditor secara signifikan berpengaruh positif terhadap efektivitas auditor Semakin tinggi independensi yang dimiliki seorang auditor, maka semakin efektif pula auditor tersebut dalam menjalankan 
tugasnya. Hasil ini ditandai dengan nilai T-statistik yang memiliki nilai >1,96 yaitu 2,807 dan $\mathrm{P}$-value $<0,05$ yaitu 0,005 .

\section{KESIMPULAN}

Penelitian ini dilakukan untuk menguji pengaruh kompetensi, hubungan auditor internal dan auditor eksternal, dukungan auditee serta independensi terhadap efektivitas audit internal. Berdasarkan pengujian yang telah dilakukan, maka dapat disimpulkan hasilnya adalah sebagai berikut

1. Variabel kompetensi auditor internal, dukungan auditee serta independensi auditor internal berpengaruh signifikan positif terhadap variabel dependen yaitu efektivitas auditor internal. Sedangkan variabel hubungan antara auditor internal dan eksternal tidak memiliki pengaruh terhadap efektivitas auditor internal.Sehingga, semakin baik kompetensi, dukungan auditee dan independensi, akan meningkatkan efektivitas audit internal.

2. Tiga dari empat variabel independen yang diteliti, yaitu kompetensi auditor internal,
dukungan
auditee
serta
independensi auditor internal
secara
bersama-sama
berpengaruh positif dan
siginifikan tehadap variabel
dependen, yakni efektivitas audit internal, dengan kemampuan variabel independen menjelaskan efektivitas audit internal sebagai variabel dependen adalah sebesar $71 \%$. Sedangkan sisanya sebesar $29 \%$ dipengaruhi oleh faktor lainnya yang tidak termasuk di dalam penelitian ini.

\section{Keterbatasan dan Saran}

Dalam penelitian ini, terdapat keterbatasan yakni jumlah sampel relatif kecil yaitu 51 responden dan hanya dalam satu instansi saja yaitu Inspektorat Provinsi Daerah Istimewa Yogyakarta. Jumlah sampel yang relatif kecil tersebut menyebabkan penelitian ini berpotensi untuk tidak dapat digeneralisasikan untuk menguji faktor-faktor yang mempengaruhi efektivitas audit internal

Saran bagi penelitian selanjutnya adalah menambah jumlah sampel penelitian yang betujuan agar hasil penelitian dapat digeneralisasikan untuk menguji efektivitas audit internal. Sampel juga perlu diperluas sehingga 
tidak terbatas pada satu instansi saja. Kemudian, perlu juga dilakukan pengkajian mengenai faktor-faktor lain yang mungkin dapat berpengaruh terhadap efektivitas audit internal.

\section{REFERENSI}

Alzeban, et al.2014. Factors Affecting The Audit internal Effectiveness: A Survey of The Saudi Public Sector. Journal of International Accounting, Auditing and Taxation.

Alzeban, A., Sawan, N. 2013. The Role of Internal Audit Function in The Public Sector Context in Saudi Arabia. Journal of Business Management.

Arens \& Loebbecke, 1997 : Auditing Pendekatan Terpadu, Salemba Empat, Jakarta

Badara, M.S., dan Saidin, S.Z. (2013). Impact of the Effective Internal Control System on the Internal Audit Effectiveness at Local Government Level. Journal of Social and Development Sciences, 16-23.

Cohen, A., dan Sayag, G. 2010. The Effectiveness of Internal Auditing: an Empirical Examination of its Determinants in Israel Organizations. Australian Accounting Review, 296-307.

Daft, Richard L. 2009. Manajemen Edisi Kelima Jilid Satu. Jakarta : Erlangga.
Efendy, M. Taufiq. 2010. "Pengaruh Kompetensi, Independensi, dan Motivasi Terhadap Kualitas Audit Aparat Inspektorat Dalam Pengawasan Keuangan Daerah". Tesis, Magister Sains Akuntansi Universitas Diponegoro Semarang.

Institute of Internal Auditors (IIA). 2006. The role of auditing in public sector governance. Florida.

Jensen, M. C and Meckling, W.H. 1976. Theory of the Firm : Managerial Behavior, Agency Costs and Ownership Structure . Journal of Financial Economics, Oktober, 1976, V. 3, No. 4, pp. 305-360.

Mardiasmo, 2004. Audit Sektor Publik. Yogyakarta: ANDI.

Meutia, Intan. 2004. Pengaruh Independensi Auditor Terhadap Manajemen Laba untuk KAP Big 5 dan Non Big 5. Jurnal Riset Akuntansi Indonesia,Vol. 7, No. 3

Mihret, Dessalegn Getie and Yismaw, Aderajew Wondim. 2007. Internal Audit EffectivenesS : an Ethiopian public sector case study. Managerial Auditing Journal, 22 (5). pp. 470-484. ISSN 0268-6902.

Sukriah, Ika, dkk. (2009). Jurnal. "Pengaruh Pengalaman Kerja, Independensi, Objektivitas, Integritas, dan Kompetensi terhadap Kualitas Hasil Pemeriksaan". Simposium Nasional Akuntansi XII, Palembang 